\title{
The 1916 New York City Epidemic of Poliomyelitis: Where did the Virus Come From?
}

\author{
H.V. Wyatt* \\ School of Philosophy, University of Leeds, Leeds LS2 9HD, UK
}

\begin{abstract}
Previous accounts of the 1916 devastating epidemic have been faulty. The unique features of the epidemic and its sudden appearance have never been explained. A New York laboratory was passaging poliovirus in primate brains, a technique which increased pathogenicity. I propose that highly virulent virus escaped and caused the epidemic. Scientists, technical and animal house staff were unaware that they could be infected by poliovirus which could then infect others. All laboratory workers must be constantly reminded of the dangers which can arise from the escape of pathogens from their work.
\end{abstract}

Keywords: Laboratory escape, New York, pathogenicity, poliomyelitis, poliovirus.

\section{Imagination is more important than knowledge. Albert Einstein}

\section{INTRODUCTION}

The 1916 epidemic, the most devastating epidemic in the history of poliomyelitis, is widely quoted in books about polio. Yet the origin of the virus has never been discussed although impressive studies of the epidemiology were made [1]. Nowadays we are aware of the danger, but in 1916, the escape of disease agents from laboratories was not considered. Later accounts have not been based on the best contemporary studies.

\section{THE EPIDEMIC}

There were 13 cases of polio in New York in January to April 1916, fewer than in any corresponding period since the disease was made reportable [1]. However, these cases were widely scattered over the whole of the city and were never considered to be part of the epidemic itself. The epidemic began with 2 children in the Italian community in Brooklyn on 8 and 9 May, with 2 more on 15 May in the next street (Fig. 1). By the end of the month there had been 24 cases in Brooklyn, of which 14 were in the vicinity of the original 13 were Italian children of which 12 were at the original locus. At the end of May there had been 5 more cases in Manhattan, of which 4 were Italian, as well as a few cases in other boroughs. On 1 June there were 17 new cases in Brooklyn and by the end of June there had been 646 cases in that borough.

After 2 weeks 150 children had been affected in five city boroughs. In spite of efforts at quarantine, by August the epidemic had spread to New Jersey, Connecticut, Pennsylvania and upstate New York, but faded out by December. In New York there had been 8,900 cases of paralysis with 2,448

*Address correspondence to this author at the 1 Hollyshaw Terrace, Leeds LS15 7BG, UK; Tel: 113246 6679; E-mail: nurhvw@leeds.ac.uk

http://sites.google.com/site/vivianwyatt/ deaths. The epidemic was thought to have affected 23000 cases with 5000 deaths through New England and the Middle Atlantic states, reaching Delaware, Maryland and the District of Columbia with a few cases in Vermont and Canada. It had no apparent connection to lesser epidemics in West Virginia and in Minnesota, Wisconsin and Michigan.

Very few children who had been present during the previous 1907 epidemic were affected in 1916, suggesting that both were probably caused by type I poliovirus. The paralytic rate among the 2 and 3 yr olds approached $2 \%$, the highest rate recorded for this age group anywhere in the world $[2,3]$, with decreasing rates to about 9 yr olds suggesting that most children in 1907 had been infected.

\section{An Extraordinary Epidemic}

The definitive account of the epidemic from the US Public Health Service [1] concluded that the outbreak had remarkable features: the extent and intensity was beyond all previous experience; the origin was remarkably definite in time and place; there was a strikingly uniform radial spread from this focus (Fig. 2) with intensity progressively decreasing in proportion to the distance from the original focus; and a demonstrable mathematical regularity in its whole evolution.

These features were never experienced again. Three other aspects were not noted at the time: the number of children age $2 \mathrm{yr}$ affected was the highest ever recorded [2, 3]; the case fatality rate of $25 \%$ was the highest ever recorded (see below); the epidemic started in early May, well before the normal summer polio season.

Although this epidemic was so severe and features in most books about polio, the only explanation advanced is the one favoured at the time - it must have been brought by children who had arrived in May from Italy. There was, however, no evidence that these children were involved 

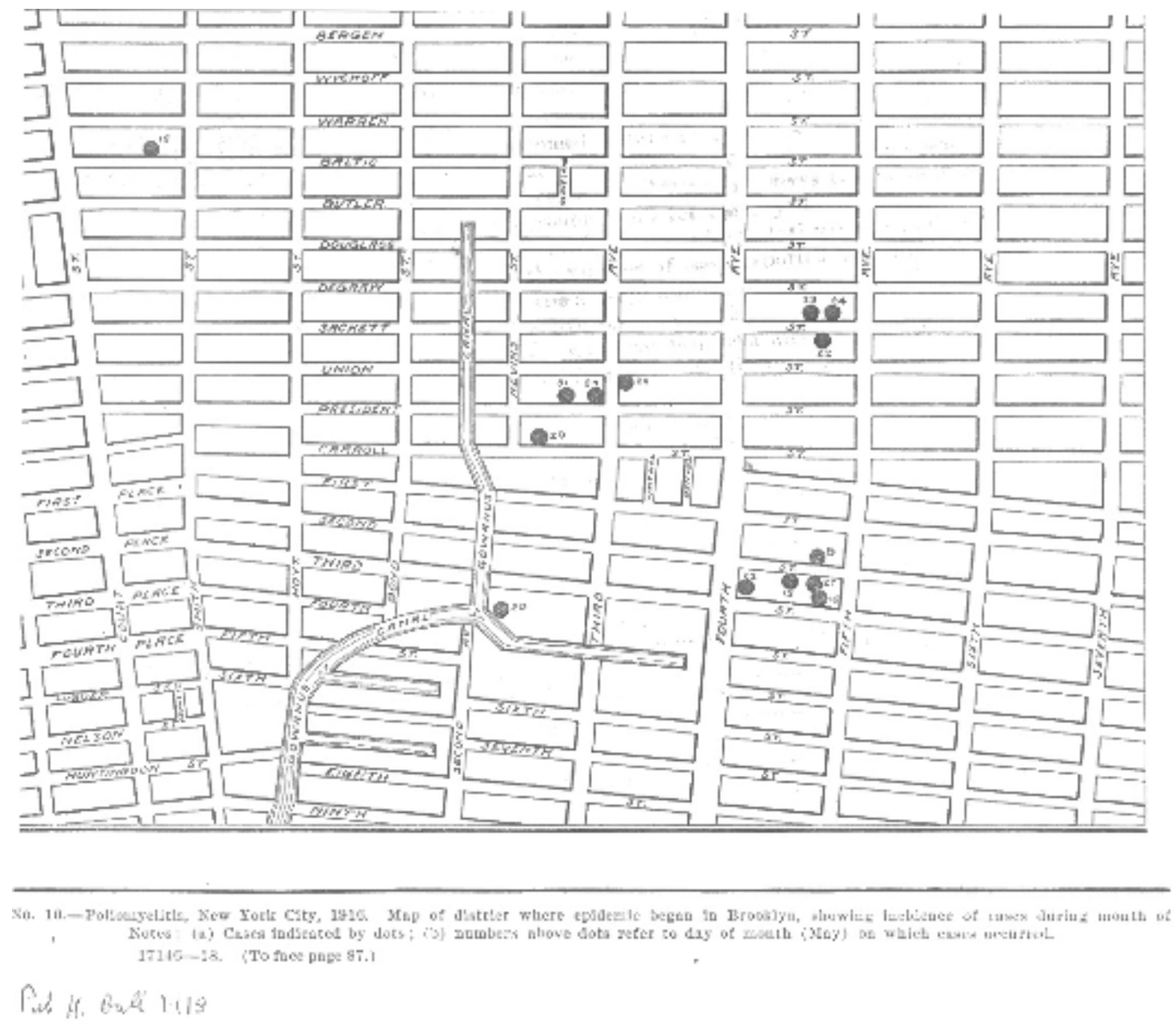

Fig. (1). The earliest cases in Brooklyn in May 1916 [from ref 1 p. 86].

and the epidemic began before they arrived. At the time, there was no real idea how polio was spread so that flies and other insects were blamed. Dogs and cats were thought to be carriers: one headline proclaimed ' 72 thousand cats killed' [4 p. 21].

The 1916 epidemic coincided with the war in Europe and was overtaken by the entry of the US against Germany in early 1917. It was then overshadowed by the great 'flu pandemic of 1918.

The epidemic is unique in having such a pronounced focus, extraordinary infectivity and very high incidence and fatality rates. The virus must have mutated to an extent never seen before or since. It was as though a new virus had suddenly been dropped at the focus. The 1916 virus was so different that several mutations would have been required and each in turn selected although no prior cases of paralysis were discovered.

\section{An Explanation}

Three miles from the epicentre of the outbreak, Simon Flexner and his associates at the Rockefeller Institute at $63^{\text {rd }}$ Street and York Avenue, near Queensborough Bridge on Manhattan Island, had been passaging spinal cord tissue containing poliovirus, from one Rhesus monkey spinal cord to another. They had been unable to infect monkeys by feeding.
These experiments continued with the passage virus which at times was reinforced with newly acquired virus from patients. When tested in 1936 by Sabin and Olitsky, this Rockefeller "MV" strain would replicate only in monkey neural cells, and no other [5]. In 1935 the MV strain was used by Brodie and Park and also by Kolmer for two ill-fated vaccines to protect against polio. Surprisingly, all of the polio histories have accepted the idea that this MV strain caused the polio cases associated with the vaccines, although it was only infective when injected into the spinal cord. None has suggested that the earlier and presumably less altered virus might be linked with the 1916 epidemic. The cases associated with the 1935 vaccines are most likely to have been caused by concurrent wild virus infection with provocation caused by the monkey spinal cord tissue of the vaccines [6].

In natural infection, poliovirus replicates in the gut and produces a viremia. In the muscles, it enters the nerve endings of the motor neurones and ascends to the spinal cord. By the time that virus enters those cells and the cells are attacked by lymphocytes, the virus cannot escape as specific antibodies are circulating in the blood. Therefore mutations for pathogenicity are accidental and occur outside the spinal cord. Passage of virus from monkey spinal cord to monkey cord, however, selects for neural mutants. In natural infections, poliovirus loses its virulence and epidemics fade as in 1916. 


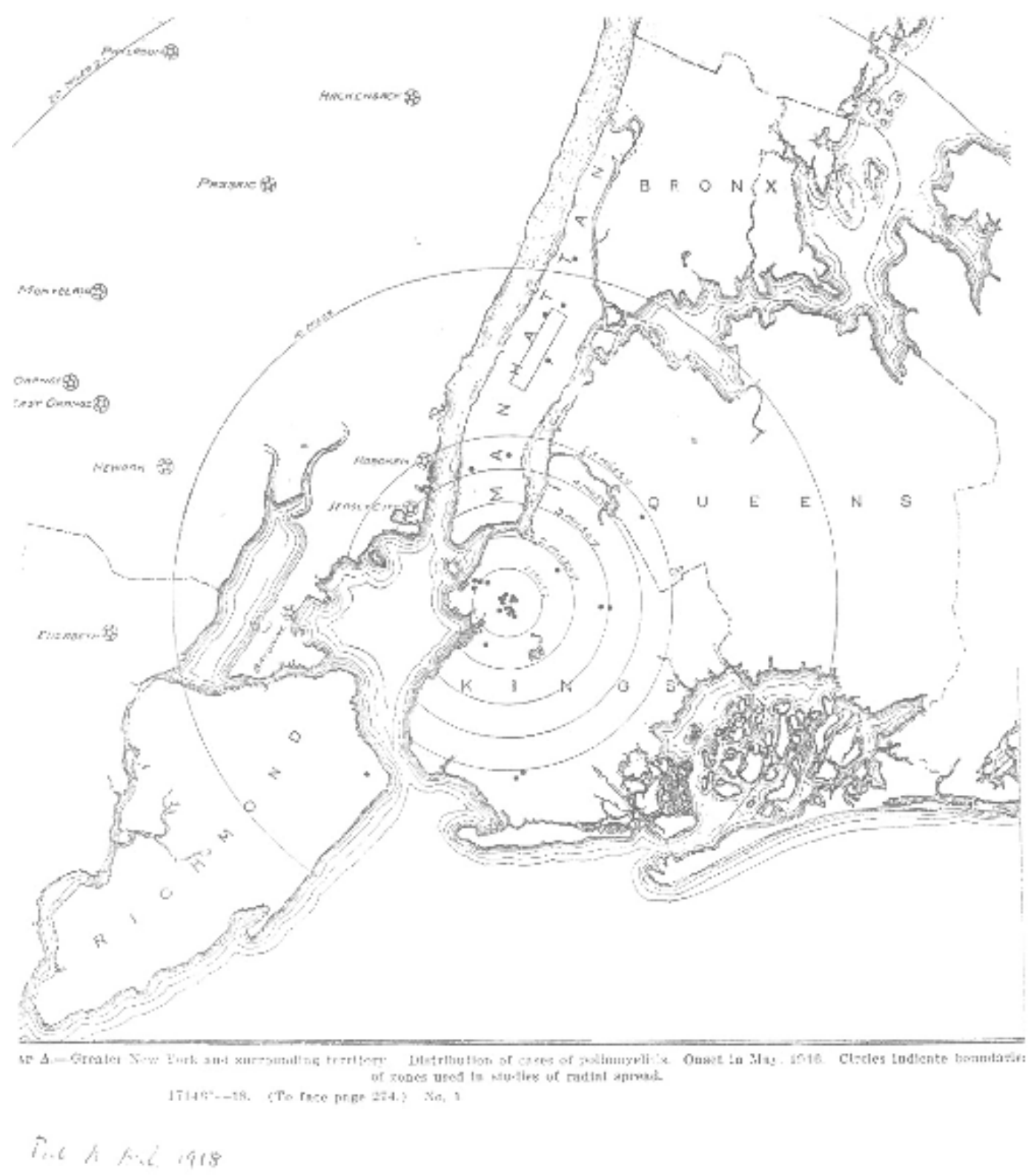

Fig. (2). The concentric spread of cases from Brooklyn [from ref 1 p. 273].

At the New York City Department of Health, doctors passaged material from polio cases in 17 Rhesus monkeys. In the middle of the largest polio epidemic ever seen, these doctors wrote that 'passage of this virus will be continued with the hope of increasing its virulence' [7 p. 88]. Why? They carried out autopsies of the monkeys in the animal house and 'the material was brought immediately to the laboratory'. I assume that this procedure was similar to that at the Rockefeller Institute.

Those doctors had no awareness of what they were handling. In the 1950's in my London hospital, the animal-house keeper was an ex-serviceman with no training. Fifteen years later at the National Cancer Institute in Bethesda, US, our animal-house attendants were young men, also without training. I suggest that the animal-house workers in 1916 were also of poor education and wages and, like the doctors, had little idea of the nature of the infected material they were using.
I suggest that by 1916, mutants of the original Rockefeller virus had been selected for replication in monkey motor neurones, but were still capable of high levels of replication in other cells. An animal-house worker might have been infected during a post-mortem examination, with accidental carriage into a household in Brooklyn and probably further dissemination in the community until it reached susceptible children without immunity. It would have been the same type that caused the 1907 epidemic which had still been circulating. With its passage through many cycles of human guts in the months that followed, it became more adapted to humans and finally lost its unique characteristics.

A few blocks from the Rockefeller Institute at Lexington Avenue and $63^{\text {rd }}$ Street the $3^{\text {rd }}$ Avenue elevated line linked at Municipal Building station to the BRT line to Brooklyn over Brooklyn Bridge with a stop at $3^{\text {rd }}$ Street and $5^{\text {th }}$ Avenue where the first case lived. However, almost anywhere in 
New York was within a few streets of a rail link to the Rockefeller Institute.

\section{DISCUSSION}

The 1916 epidemic is featured in many accounts of polio, but details and emphases differ and many are incorrect. The early cases in May in Brooklyn had not been reported, but were found at a later date by the USPHS researchers. Writers seem to have missed these early cases so that the mistaken suggestion that the epidemic arose from Italian child emigrants took hold [4]. Offit said that the first two cases of the epidemic occurred on 6 June [8]. Rogers had a graph with the first cases occurring in early June [9]. Rivers said 'the epidemic actually began in mid-June but was still raging in September': his sole comments were about the opening of schools before the epidemic was over [10]. Paul, in his excellent history of polio, devoted a chapter to the epidemic, but only discussed quarantine, research projects and the career of Haven Emerson [11]. The start of the epidemic before the usual summer dates was therefore missed by these authors. The only work to mention the early appearance in May is a quote from the New York Times of 6 July 'since May $15 \ldots$ where the outbreak appeared at about the date named' [12]. Even this date is a week later than the first case on 8 May.

The New York Health Department doctors gave 'immune sera' to a few monkeys, but these treatments were probably harmful [7]. No date was given so that we cannot know whether the shortage of monkeys was due to the use of at least 17 to passage virus to produce a more virulent strain - a curious priority. The high case-fatality rate of about $25 \%$ was not discussed. This rate was based on the total number of recorded cases, including many which were non-paralytic. As the epidemic spread through New England the rate fell to $18 \%$. A better comparison uses only paralytic cases, so the 1916 rate might have been nearer $50 \%$. In India a casefatality of about $2 \%$ has been based on nearly 200000 paralytic cases [13]. How far the high death rate in 1916 was due to treatment will be explored in another paper.

Since the escape of smallpox virus from research laboratories in England in 1973 and 1978 [14, 15], we have become acutely aware of the need for containment of infectious agents: in 1916 - and for many decades after - many workers were unaware of the dangers. While diseases were present outside the laboratory, reinforcement from cultures or infected animals was not considered. The enquiry into the 1973 escape showed that more than $50 \mathrm{yr}$ after the New York epidemic, dangerous practices still continued eg lab coats were not routinely autoclaved even when they might be contaminated. This escape killed two persons at third (or fourth) hand with no recognised illness in between [14]. The smallpox escapes were only found because smallpox was no longer endemic in Britain and finding the source of the virus was vital. Flexner's rigid separation of research from clinical aspects [11p.118] meant that the researchers at the Rockefeller Institute took no part in the epidemic. If they had compared the epidemic virus with their own MV strain, they might have noticed similarities.
Polio has a particularly hidden risk as it was not realised that adults with immunity could be infected and shed virus, infecting other adults as well as children. Most infected children would also shed virus, but without any symptoms. Some years ago I visited an Indian laboratory which monitored stools sent from paralysed children. The scientist in charge was unaware that staff who handled the stools could be infected and shed virus in the community even though they were themselves immune.

Billions of doses of oral poliovirus have been given and only a handful of reversions to greater virulence have been found. In the episodes following these reversions, there have been few cases of paralysis and no epidemics to compare with 1916. Nevertheless, throughout the world, WHO is destroying all samples which might contain poliovirus, except those used for vaccine production. The Salk vaccine uses the virulent Type I strain which might be very dangerous if it escaped from the manufacturing sites. It might be wise to regularly test the stools of all who work with polioviruses.

\section{CONCLUSION}

It is not possible to prove that the 1916 epidemic was caused by the escape of MV from the Rockefeller Institute. Neither can we know if there have been other escapes of poliovirus from laboratories. However it is a remarkable coincidence that a unique neurotropic strain of poliovirus was developed a few miles from an epidemic caused by a uniquely pathogenic strain of the virus. My theory would not be proved even if it could be shown that a Rockefeller worker had lived in Brooklyn. Nevertheless such an extraordinary epidemic requires an extraordinary explanation: it is the only suggestion to be offered so far. Correct or not, it provides a powerful message for everyone who works with pathogens.

\section{REFERENCES}

[1] Lavinder, C.H.; Freeman, A.W.; Frost, W.H. Epidemiological studies of poliomyelitis in New York City and North Eastern United States during the year 1916. Public Health Bull., 1918, 91, 35 .

[2] Wyatt, H.V. Is poliomyelitis a genetically-determined disease? I A genetic model. Med. Hypotheses, 1975, 1, 35-42.

[3] Wyatt, H.V. Is poliomyelitis a genetically-determined disease ? II A critical examination of the epidemiological data. Med. Hypotheses, 1975, 1, 87-96.

[4] Oshinsky DM. Polio. An American story. OUP, 2005.

[5] Sabin, A.B.; Olitsky, P.K. Cultivation of poliomyelitis virus in vitro in human embryonic nervous tissue. Proc. Soc. Exp. Biol. Med., 1936, 64, 357-359.

[6] Wyatt, H.V. Provocation poliomyelitis: neglected clinical observations from 1914 to 1950. Bull. Hist. Med., 1981, 55, 543-557.

[7] Anon. Monograph on the Epidemic of Poliomyelitis (infantile paralysis) in New York City in 1916. New York City Department of Health, New York, 1917.

[8] Offit, P.A. The Cutter Incident. How America's first Polio Vaccine Led to the Growing Vaccine Crisis. Yale University Press: USA, 2005.

[9] Rogers, N. Dirt and Disease. Polio before FDR. Rutgers University Press: USA, 1992.

[10] Benison, S. Tom Rivers. Reflections on a Life in Medicine and Science. The MIT Press: USA, 1967.

[11] Paul, J.R. A History of Poliomyelitis. Yale University Press: USA, 1971. 
[12] Gould, T. A Summer Plague. Polio and its survivors. Yale University Press: USA, 1995

[13] Wyatt, H.V. Poliomyelitis and infantile paralysis: changes in host and virus. Hist. Philos. Life Sci., 1993, 15, 357-396.
[14] Coc, P.J.; McCarthy, K.; Millar, E.L. Report of the Committee of Inquiry into the Smallpox Outbreak in London in March and April 1973. HMSO, London, 1974.

[15] Shooter, R.A. Report of the Investigation into the Cause of the 1979 Birmingham Smallpox Occurance. HMSO: London, 1980.

Received: January 24, 2011

Revised: April 08, 2011

Accepted: April 13, 2011

(C) H.V. Wyatt; Licensee Bentham Open.

This is an open access article licensed under the terms of the Creative Commons Attribution Non-Commercial License (http://creativecommons.org/licenses/by$\mathrm{nc} / 3.0 /$ ) which permits unrestricted, non-commercial use, distribution and reproduction in any medium, provided the work is properly cited. 